\title{
KHITAN PEREMPUAN DALAM FATWA MUI NO. 9A TAHUN 2008 DAN PERMENKES NO. 6 TAHUN 2014 PERSPEKTIF MAQASHID AL-SYARI'AH
}

\author{
1Erik Sabti Rahmawati dan ${ }^{2}$ Lukluil Maknun \\ 1,2Universitas Islam Negeri Maulana Malik Ibrahim Malang \\ 1'dhavha.fitri@gmail.com
}

\begin{abstract}
This study aims to (1) find out the foundations affecting the issuance of MUI instruction and PERMENKES, and (2) explain the female circumcision in MUI instruction and PERMENKES by using maqashid al-syari'ah review. This research is a literature research. This study obtained two research results, (1) the basis of the issue of MUI instruction No.9A Year 2008 is to revive the sunnah of circumcision on women as a sign of glorification for women. While the foundation of the publication of PERMENKES is caused by the phenomenon of unhygienic female circumcision practices that tend to eliminate female libido. (2) if reviewed using maqashid al-syari'ah, female circumcision in MUI instruction emphasize on spreading Islam that is hifdz al-diin (keeping religion) and hifdz al-nafs (keep spirit). While female circumcision in PERMENKES more emphasis on hifdz al-nafs (keeping spirit), because if the implementation of the circumcision by eliminating totally or part of female genital organs, then it will adversely affect the physical and also psychological woman.
\end{abstract}

Key Words: Circumcision; MUI Fatwa; PERMENKES; Maqashid Al-Syari'ah.

\section{Abstrak}

Penelitian ini bertujuan untuk (1) mengetahui landasan-landasan yang mempengaruhi terbitnya fatwa MUI dan PERMENKES, dan (2) menjelaskan khitan perempuan dalam fatwa MUI dan PERMENKES dengan menggunakan tinjauan maqashid al-syari'ah. Penelitian ini berupa literature research (penelitian kepustakaan). Kemudian pendekatan yang digunakan dalam penelitian ini adalah pendekatan komparatif dengan tujuan untuk memperoleh persamaan dan perbedaan tentang khitan perempuan dalam Fatwa MUI No.9A Tahun 2008 dan PERMENKES No.6 Tahun 2014. Dalam penelitian ini diperoleh dua hasil penelitian, (1) landasan terbitnya Fatwa MUI No.9A Tahun 2008 ialah untuk menghidupkan sunnah adanya khitan pada perempuan sebagai tanda pemuliaan bagi para perempuan. Sedangkan landasan terbitnya PERMENKES ialah disebabkan oleh adanya fenomena praktek khitan perempuan yang tidak higienis yang cenderung menghilangkan libido perempuan. (2) jika ditinjau menggunakan maqashid al-syari'ah, khitan perempuan dalam fatwa MUI menekankan pada syiar Islam yaitu hifdz al-diin (menjaga agama) dan hifdz al-nafs (menjaga jiwa). Sedangkan khitan perempuan dalam PERMENKES lebih menekankan pada hifdz al-nafs (menjaga jiwa), karena jika pelaksanaan khitan tersebut dengan menghilangkan secara total atau sebagian dari organ kelamin wanita, maka itu akan berdampak buruk pada fisik dan juga psikis seorang perempuan.

Kata Kunci: Khitan; Fatwa MUI; PERMENKES; Maqashid Al-Syari'ah. 


\section{PENDAHULUAN}

Islam sangat memperhatikan perlindungan untuk setiap individu, yakni melalui perlindungan untuk urusan individu yang bersifat materi dan moral, juga termasuk didalamnya masalah kebersihan dan kesehatan. Dalam ajaran Islam yang berkaitan dengan kebersihan dan pemeliharaan kesehatan antara lain meliputi thaharah, khitan, penyelenggaraan jenazah, hygiene dalam hidup, kehamilan, pemeliharaan anak, pengaturan makanan, memotong kuku, membersihkan (merapikan) bulu di sekitar tubuh, merapikan kumis, dan sebagainya (Alhafidz, 2007). Khitan atau sering disebut dengan sunat, merupakan bagian dari ajaran Islam yang bertujuan untuk menjaga kesucian dan kesehatan. Khitan juga merupakan salah satu persoalan yang masih di perselisihkan oleh ulama, baik pada zaman dahulu maupun pada zaman sekarang (Subhan, 2008).

Khitan berawal pada tradisi Nabi Ibrahim as. Beliau adalah orang yang pertama kali dikhitan. Pelaksanaan khitan Nabi Ibrahim AS tersebut menjadi simbol dan tanda ikatan perjanjian suci (mitsaq) antara dia dengan Allah. Khitan adalah suatu kegiatan yang telah menjadi tradisi di berbagai belahan dunia dan sampai sekarang masih di lakukan oleh penganut Islam, Yahudi, dan sebagian penganut Kristen. Namun bagi penganut Koptik Kristen dan Yahudi, khitan bukanlah hanya sebagai suatu proses bedah kulit bersifat fisik semata, akan tetapi juga menunjuk arti dan esensi kesucian (Subhan, 2008).

Khitan bagi laki-laki yang telah membudaya di berbagai belahan dunia dilaksanakan dalam bentuk yang hampir sama, yaitu pemotongan kulup penis (kulit kepala dzakar) laki-laki. Khitan akan mencegah kotoran pada dzakar, karena kotoran ini berada pada bagian bawah kulup yang menjadi pusat berkembangbiaknya bakteri. Jika kulup itu tidak dihilangkan dan masih menutup dzakar, maka bagian yang peka ini akan selalu bergesekan dengan pakaian, sehingga menyebabkan syaraf yang merupakan daerah peka menjadi berkurang (Alfanjari, 2005).

Khitan tidak hanya berlaku untuk laki-laki, akan tetapi juga untuk anak perempuan. Praktik khitan pada perempuan telah lama dikenal sejak zaman Mesir Kuno. Hal itu di buktikan dengan ditemukannya fenomena khitan pada mummi perempuan yang hidup pada abad ke-16 SM (16 SM) jauh sebelum Islam datang. Praktik khitan ini juga masih berlangsung di beberapa Negara Arab seperti Sudan, Yaman, dan sebagian Negara Teluk dan bahkan di Indonesia (Utomo, 2003).

Khitan bagi perempuan atau biasa disebut dengan khifadh biasa dilakukan dengan memotong sebagian kecil dari kulit kemaluan yang menonjol di atas lubang kencing. Namun dalam hal ini Rasulullah SAW mengingatkan bahwa dalam memotongnya tidak boleh berlebihan. Disebutkan dalam sebuah riwayat dari Anas bin Malik dikatakan bahwa Rasulullah SAW bersabda: "jika kamu menghitan (perempuan), potonglah pada bagian terdekat, janganlah 
kamu memotongnya terlalu dalam, karena hal itu membuat indah wajah dan menyenangkan suami" (Alhafidz, 2007, p. 100).

Di Indonesia, arti penting yang diberikan oleh keperawanan dan selaput darah yang utuh pada masyarakat ini merupakan sebuah alasan mengapa khitan perempuan masih dijalankan secara luas meski tumbuh kecenderungan saat ini untuk meninggalkannya, karena dianggap ketinggalan dan membahayakan. Dibalik makna penyunatan, terdapat kepercayaan bahwa dengan membuang bagian-bagian tertentu dari organ kelamin luar seorang gadis, hasrat seksual bisa dikurangi. Ini mengharuskan seorang wanita yang mencapai usia rawan puberitas dan keremajaan untuk menjaga keperawanan serta kehormatannya dengan sangat hati-hati (Siraj, 2013).

Pada masa dahulu, di Indonesia, khitan sering dilaksanakan pada anak-anak perempuan saat berusia 17 atau 18 tahun (sebelum memasuki masa menstruasi). Praktek khitan yang dilakukan di pedesaan lebih mengandalkan tenaga dukun setempat, sehingga banyak terjadi kasus komplikasi yang muncul akibat operasi primitif yang membahayakan jiwa seorang gadis (Siraj, 2013).

Beberapa dukun khitan percaya bahwa penyunatan yang efektif yaitu memerlukan potongan yang dalam dengan sebuah silet untuk menjamin pemotongan klitoris sempurna agar tidak ada bagian organ sensitif seksual yang tersisa. Dengan demikian pendarahan yang banyak menjadi peristiwa yang biasa bahkan terkadang mengakibatkan kematian (Siraj, 2013).

Selain dilakukan oleh dukun, khitan di Indonesia juga dilakukan oleh tenaga kesehatan tertentu, yaitu dokter, bidan, dan perawat yang telah memiliki surat izin praktik, atau surat izin kerja. Menurut tim medis, khitan atau sunat perempuan diindikasikan sebagai upaya untuk pencegahan penyakit atau penanggulangan kelainan yang berkaitan dengan adanya prepusium, seperti kelainan kulit yang bertangkai dengan permukaan berjonjot, tumor ganas, dan lain sebagainya (Alhafidz, 2007).

Menanggapi PMK No.1636 Tahun 2010 tersebut, Menteri Kesehatan mengeluarkan peraturan terbarunya yaitu PERMENKES No. 6 Tahun 2014 Tentang Pencabutan PERMENKES No. 1636/MENKES/PER/XI/2010 Tentang Sunat Perempuan. Menteri Kesehatan menilai, sunat perempuan hingga saat ini tidak termasuk tindakan kedokteran, karena pelaksanaannya tidak berdasarkan indikasi medis dan belum terbukti bermanfaat bagi kesehatan. Selain itu, khitan perempuan juga dipandang sudah tidak sesuai lagi dengan dinamika perkembangan kebijakan global (Kementerian Kesehatan RI, 2014).

Masalah khitan perempuan juga dibahas dalam fatwa MUI diawali dengan adanya penegasan bahwa khitan baik bagi laki-laki maupun perempuan termasuk fitrah (aturan) dan syiar Islam. Hal ini menjadi penting untuk ditegaskan terkait dengan adanya kesalahpahaman 
terhadap posisi khitan. Khitan tidak hanya sekedar kebutuhan medis, namun merupakan bentuk ibadah yang "dogmatik" (Konsideran Fatwa MUI-DIY No. 9A Tahun 2008).

Meskipun secara medis tidak (lebih tepatnya belum) ditemukan manfaat terhadap pelaksanaan khitan bukan serta merta ia menjadi terlarang. Hal ini sangat berbeda dengan cara pandang medik ansich. Cara pandang yang seperti ini dipastikan akan melarang khitan jika tidak ada pertimbangan medis (Konsideran Fatwa MUI-DIY No. 9A Tahun 2008).

Namun demikian fatwa MUI juga tidak menutup mata terhadap fakta adanya berbagai praktek khitan perempuan yang menimbulkan bahaya. Maka dari itu, untuk mengindari adanya bahaya akibat penyimpangan terhadap praktek khitan perempuan, Fatwa MUI juga menegaskan mengenai batasan atau tata cara khitan perempuan sesuai dengan ketentuan syari'ah, sebagaimana tersebut dalam diktum ketiga fatwa MUI. Penentuan batasan atau tata cara khitan tersebut didasarkan pada petunjuk yang diberikan Nabi SAW yang menekankan pada 3 prinsip, yaitu: a) sedikit saja, b) tidak berlebihan, dan c) tidak menimbulkan bahaya (Konsideran Fatwa MUI-DIY No. 9A Tahun 2008).

Dalam penelitian ini, penulis juga memaparkan beberapa penelitian-penelitian sebelumnya yang penulis tulis dalam bentuk tabel sebagai berikut:

\begin{tabular}{|c|c|c|c|}
\hline No. & Peneliti/Tahun & Judul Penelitian & Pembahasan \\
\hline 1. & $\begin{array}{c}\text { Erowati/STAIN } \\
\text { Pekalongan/2012 }\end{array}$ & $\begin{array}{c}\text { Khitan bagi Perempuan } \\
\text { dalam Perspektif Hukum } \\
\text { Islam }\end{array}$ & $\begin{array}{c}\text { Hukum khitan dalam pandangan } \\
\text { Imam empat Madzhab dan } \\
\text { mayoritas ulama yaitu makrumah. }\end{array}$ \\
\hline 2. & $\begin{array}{c}\text { Taufiq } \\
\text { Hidayatullah/UIN } \\
\text { Sunan Kalijaga/ } \\
2010\end{array}$ & $\begin{array}{c}\text { Khitan Wanita } \\
\text { Perspektif Hukum Islam } \\
\text { dan Kesehatan }\end{array}$ & $\begin{array}{c}\text { Pandangan khitan dalam perspektif } \\
\text { hukum Islam dan ahli kesehatan } \\
\text { ialah lebih menolak khitan wanita } \\
\text { relevansinya terhadap masa } \\
\text { sekarang. }\end{array}$ \\
\hline 3. & $\begin{array}{c}\text { Sauki/UIN Syarif } \\
\text { Hidayatullah/ } \\
\text { 2010 }\end{array}$ & $\begin{array}{c}\text { Khitan Perempuan } \\
\text { Perspektif Hadits dan } \\
\text { Sirkumsisi Perempuan } \\
\text { Menurut WHO }\end{array}$ & $\begin{array}{c}\text { Hadits tentang sirkumsisi } \\
\text { perempuan adalah bersifat lemah } \\
\text { dan tidak shahih serta bukan } \\
\text { merupakan tuntunan langsung dari } \\
\text { Islam. }\end{array}$ \\
\hline
\end{tabular}

Dari ketiga penelitian tersebut, dapat diketahui bahwasanya fokus penelitian yang dilakukan penulis memiliki perbedaan dari penelitian-penelitian sebelumnya. Dimana pada penelitian pertama membahas tentang hukum khitan dalam pandangan Imam empat Madzhab dan mayoritas ulama yang menetapkan bahwa khitan perempuan adalah makrumah. Kemudian penelitian kedua membahas tentang pandangan khitan dalam perspektif hukum Islam dan ahli kesehatan ialah lebih menolak khitan wanita relevansinya terhadap masa sekarang. Adapun penelitian ketiga membahas hadits tentang sirkumsisi perempuan adalah bersifat lemah dan tidak shahih serta bukan merupakan tuntunan langsung dari Islam. Berbeda dengan ketiga penelitian tersebut, penelitian ini lebih memfokuskan khitan perempuan menurut pandangan MUI dan juga Menteri Kesehatan yang memiliki perbedaan dalam menetapkan fatwa dan juga 
peraturannya. Selain itu, penulis membandingkan khitan perempuan dalam fatwa MUI dan juga peraturan Menteri tersebut dengan meggunakan perspektif Maqashid al-Syari'ah.

Dari beberapa fenomena yang telah dijabarkan, maka dari itu penulis tertarik untuk membuat karya tulis ini. Adapun tujuannya yaitu ingin mengetahui landasan terbitnya fatwa MUI No. 9A Tahun 2008 dan juga PERMENKES No. 6 Tahun 2014. Serta mengetahui bagaimana khitan perempuan dalam fatwa MUI No. 9A Tahun 2008 dan juga PERMENKES No. 6 Tahun 2014 dalam perspektif Maqashid al-Syari'ah.

\section{METODE PENELITIAN}

Jenis penelitian ini termasuk penelitian normatif, karena penulis melakukan penelitian dengan cara meneliti bahan pustaka atau data sekunder saja atau juga dapat disebut dengan penelitian kepustakaan (literature research). Selanjutnya, pendekatan penelitian yang digunakan adalah pendekatan komparatif, karena dilakukan dengan cara membandingkan khitan perempuan dalam Fatwa MUI No. 9A Tahun 2008 dengan PERMENKES No. 6 Tahun 2014, yang bertujuan untuk memperoleh persamaan dan perbedaan diantara keduanya.

Kemudian jenis data yang digunakan dalam penelitian normatif adalah data sekunder yang terdiri dari bahan hukum primer dan bahan hukum sekunder (Amiruddin \& Asikin, 2010). Dalam hal ini, bahan hukum primer yang peneliti gunakan adalah Fatwa MUI, dan PERMENKES. Sedangkan untuk bahan hukum sekunder, peneliti menggunakan buku-buku tentang khitan perempuan, seperti: Nilai Kesehatan dalam Syari'at Islam, Menggagas Fiqh Pemberdayaan Perempuan, Fiqh Aktual, Fikih Kesehatan, dan juga Lembar Negara, seperti: Berita Negara Republik Indonesia Tahun 2014 Nomor 185, PERMENKES No. 6 tahun 2014 Tentang Pencabutan PMK No. 1636/MENKES/PER/XI/2010 Tentang Sunat Perempuan. Selain dari buku-buku, penulis juga mengambil referensi dari artikel yang membahas tentang khitan perempuan, seperti: Khitan bagi Perempuan ditinjau dari Kesehatan dan Islam, Fatwa MUI tentang Khitan Perempuan, Pencabutan PERMENKES tentang Sunat Perempuan, Peraturan Menteri Kesehatan RI Soal Sunat Perempuan Telah Dicabut, dan Polemik Khitan Wanita.

Selanjutnya, metode pengumpulan bahan hukum yang digunakan dalam penelitian ini adalah metode dokumentasi yaitu seperti Fatwa MUI, Peraturan Menteri Kesehatan, buku dan artikel yang membahas tentang khitan perempuan khususnya literatur dari Fatwa MUI No. 9A Tahun 2008 dan PERMENKES No. 6 Tahun 2014.

Metode penelitian terakhir yang penulis gunakan ialah metode pengolahan data dan analisis bahan hukum yang terdiri dari proses editing, yaitu penyeleksian atau pemeriksaan ulang terhadap sumber-sumber data atau bahan hukum yang telah terkumpul (Sayuti, 1989), meliputi Fatwa MUI, Peraturan Menteri Kesehatan, buku dan artikel yang membahas tentang khitan perempuan. Proses selanjutnya ialah proses classifying yaitu mengklasifikasikan sumber- 
sumber data. Hal ini dilakukan agar peneliti lebih mudah dalam melakukan pengelompokan sumber-sumber bahan hukum, yaitu dari Fatwa MUI, Peraturan Menteri Kesehatan, buku dan artikel yang membahas tentang khitan perempuan.

Kemudian menggunakan proses verifying yaitu memeriksa kembali data-data informasi yang ada agar validitasnya bisa terjamin (Abdullah \& et al., 2006), dilakukan dengan cara sumber-sumber bahan hukum, seperti Fatwa MUI, Peraturan Menteri Kesehatan, buku dan artikel yang membahas tentang khitan perempuan digabungkan dengan pokok permasalahan yang diteliti dengan metode perbandingan atau komparasi, yaitu fatwa MUI No. 9A Tahun 2008 dan PERMENKES No. 6 Tahun 2014 mengenai khitan bagi perempuan dalam tinjauan Maqashid Al-Syari'ah. Selanjutnya proses terakhir yaitu menganalisis data dengan menggunakan analisis deskriptif kualitatif komparatif, kemudian mengambil kesimpulan dari hasil analisis diatas yang berkaitan dengan khitan perempuan dalam tinjauan Maqashid Al-Syari'ah melalui perbandingan dua sumber hukum, yaitu fatwa MUI No.9A Tahun 2008 dan PERMENKES No.6 Tahun 2014.

\section{HASIL DAN PEMBAHASAN}

\section{Landasan Terbitnya Fatwa MUI dan PERMENKES tentang Khitan Bagi Perempuan}

Masyarakat di Indonesia sering merasakan kebingungan terhadap suatu perkara yang masih belum jelas atau belum tetap hukumnya, seperti perkara khitan bagi perempuan. Khitan bagi perempuan ini merupakan sebuah implementasi pemikiran yang salah, yang tersebar di tengah-tengah pemeluk agama lain (Siraj, 2013). Selain itu juga terjadi beragam tata cara pelaksanaan khitan bagi perempuan yang tidak jarang berimplikasi terhadap adanya dlarar (bahaya) bagi perempuan, ada yang dengan cara menggores dan mengerik, menusuk, mencubit dan menindik insisi serta eksisi (Konsideran Fatwa MUI-DIY No. 9A Tahun 2008).

Terdapat kepercayaan bahwa dengan membuang bagian-bagian tertentu dari organ kelamin luar seorang gadis, hasrat seksualnya dapat dikurangi. Namun berbeda dengan kepercayaan yang di pegang teguh oleh dukun-dukun yang akan mengkhitan perempuan. Para dukun memiliki kepercayaan bahwa penyunatan yang efektif ialah memerlukan potongan yang dalam dengan sebuah silet untuk menjamin pemotongan klitoris menjadi sempurna, dan agar tidak ada bagian organ sensitif seksual yang tersisa. Hal ini mengakibatkan banyaknya pendarahan yang bahkan terkadang dapat mengakibatkan kematian ((Siraj, 2013).

Dalam ajaran Islam, secara umum khitan perempuan hukumnya adalah khilaf (perbedaan) antara wajib, makrumah dan sunnah. Namun menurut MUI seperti yang telah di sebutkan diatas, hukum khitan bagi perempuan adalah makrumah (bentuk pemuliaan). Kemudian juga dalam literatur fiqh tidak ditemukan satu pun ulama madzhab fiqh yang mu'tabar (terkenal) melarang praktek khitan prempuan. Bahkan terdapat kesepakatan bahwa khitan perempuan adalah bentuk keutamaan seperti halnya yang terdapat dalam fatwa MUI. 
Hanya saja terdapat perbedaan hukum fiqh-nya antara sunnah dan wajib (Konsideran Fatwa MUI-DIY No. 9A Tahun 2008).

Selanjutnya, dalam diktum ketiga fatwa MUI terdapat substansi tentang khitan bagi perempuan yang terdiri dari 4 bagian, yaitu: (a) status hukum khitan perempuan adalah makrumah, dan pelaksanaannya adalah sebagai salah satu bentuk ibadah yang dianjurkan, (b) hukum pelarangan khitan terhadap perempuan bertentangan dengan ketentuan syari'ah, karena bagi laki-laki atau perempuan khitan termasuk fitrah (aturan) dan syiar Islam, (c) batas atau cara khitan perempuan meliputi: khitan bagi perempuan cukup dengan hanya menghilangkan selaput (jaldah/colum/prapaeputium) yang menutupi klitoris, khitan bagi perempuan tidak boleh dilakukan secara berlebihan, seperti memotong atau melukai klitoris (insisi dan eksisi) yang mengakibatkan dloror (bahaya dan merugikan), dan (d) rekomendasi yang ditujukan kepada pemerintah cq. Departemen Kesehatan untuk menjadikan fatwa ini sebagai acuan dalam penetapan peraturan/regulasi tentang masalah khitan perempuan, dan juga untuk memberikan penyuluhan dan pelatihan kepada tenaga medis untuk melakukan khitan perempuan sesuai dengan ketentuan fatwa ini (Konsideran Fatwa MUI-DIY No. 9A Tahun 2008).

Berdasarkan substansi tersebut, sebenarnya MUI hanya ingin menegaskan 2 hal sekaligus, yaitu: (1) menegaskan tindak pelarangan khitan terhadap perempua, dan (2) menegaskan tata cara berkhitan pada perempuan yang sesuai dengan ketentuan syari'ah serta melarang tindakan berlebihan dalam praktek khitan yang menimbulkan bahaya bagi perempuan, baik secara fisik maupun psikis (Konsideran Fatwa MUI-DIY No. 9A Tahun 2008).

Alasan atau argumentasi dalam penetapan fatwa tersebut diatas diawali dengan khitan perempuan baik bagi laki-laki maupun perempuan adalah merupakan fitrah (aturan) dan termasuk syariat Islam dan pelaksanaannya merupakan bagian dari ibadah. Menurut MUI, hal ini sangat penting untuk ditegaskan terkait adanya kesalahpahaman mengenai posisi khitan bagi perempuan. Karena khitan bukan hanya sekedar kebutuhan medis, melainkan juga salah satu bentuk ibadah yang "dogmatik" (Konsideran Fatwa MUI-DIY No. 9A Tahun 2008).

MUI juga memberikan gambaran secara sederhana tentang pengambilan sikap terhadap masalah khitan bagi perempuan, yaitu terdapat 2 kutub yang berlawanan: (1) Pihak yang melakukan khitan terhadap perempuan dengan praktek yang secara pasti membahayakan, seperti dengan menjepit dan sejenisnya, menutup dan menjahit vagina, mengambil seluruh klirotis dan labia baik mayora maupun minora, serta praktek lain yang membahayakan, sebagaimana yang terjadi di beberapa negara Afrika Utara. (2) Pihak yang melarang seluruh praktek khitan perempuan, dengan alasan sebagai bentuk kekerasan, mutilasi dan pelanggaran hak asasi manusia. Sebagai sebuah lembaga yang mengayomi seluruh masyarakat muslim di Indonesia, MUI menjadi penengah diantara kedua ekstrim tersebut. Karena menurutnya, kedua 
ekstrim itu baik secara akademik maupun keagamaan sangat bertentangan dengan ketentuan normatif yang dikembangkan dalam Islam (Konsideran Fatwa MUI-DIY No. 9A Tahun 2008).

Penentuan batasan atau tata cara berkhitan terhadap perempuan tersebut, lebih menekankan pada 3 prinsip berdasarkan petunjuk yang diberikan Nabi SAW, yaitu: sedikit saja, tidak berlebihan, dan tidak menimbulkan bahaya. Ketentuan ini juga telah sesuai dengan hukum Islam yaitu untuk menjaga agama dan jiwa seorang perempuan (Konsideran Fatwa MUI-DIY No. 9A Tahun 2008).

Selain dibahas oleh MUI, khitan perempuan juga dibahas dalam Peraturan Menteri Kesehatan (PERMENKES). Dalam upaya memberikan perlindungan pada perempuan, terutama dalam hal khitan, Menteri Kesehatan mengeluarkan peraturan yang mengatur tentang Sunat Perempuan yang tertuang dalam PMK No. 1636/2010. Pada peraturan tersebut, Menteri Kesehatan menegaskan bahwa khitan hanya dapat dilakukan oleh tenaga medis tertentu yang dapat memberikan pelayanan khitan pada perempuan seperti dokter, bidan, dan perawat yang memiliki surat izin praktek. Menteri Kesehatan juga mencantumkan syarat-syarat dalam pelaksanaan sunat perempuan, seperti: dilakukan di ruangan dan tempat tidur/meja tindakan yang bersih, menggunakan alat-alat yang steril, mendapat pencahayaan yang cukup, dan juga menggunakan air bersih yang mengalir (Kementerian Kesehatan RI, 2010).

Selain mencantumkan syarat-syarat, Menteri Kesehatan juga menentukan laranganlarangan seperti: (1) sunat perempuan tidak dapat dilakukan pada perempuan yang sedang menderita infeksi genitalia eksterna dan/atau infeksi umum, (2) dilarang melakukan sunat perempuan dengan cara: a) mengkauterisasi klitoris, b) memotong atau merusak klitoris baik sebagian maupun seluruhnya, dan c) memotong atau merusak labia minora, labia majora, hymen atau selaput darah dan vagina, baik sebagian maupun seluruhnya (Kementerian Kesehatan RI, 2010).

Keberlakuan PMK No. 1636/2010 hanya berlangsung kurang lebih selama 4 tahun. Karena kemudian peraturan ini di cabut dengan di berlakukannya PERMENKES No. 6 Tahun 2014 tentang Pencabutan PMK No. 1636/2010 tentang Sunat Perempuan. Selanjutnya, terdapat beberapa kelompok aktivis perempuan yang mendukung keberlakuan PERMENKES No. 6/2014 tersebut. Menurut para kelompok aktivis perempuan, PMK No. 1636/2010 yang bersifat "permisif" terhadap khitan/sunat perempuan justru dapat memicu praktek sunat ilegal terhadap anak perempuan. Penggunaan jarum dan penjelasan langkah-langkah yang harus diambil oleh tenaga medis, dinilai dapat memicu terjadinya perlukaan dan trauma pada wanita (Kementerian Kesehatan RI, 2010).

Dalam PERMENKES No.6 Tahun 2014, juga telah ditetapkan bahwa PMK No. 1636/MENKES/PER/XII/2010 tentang Sunat Perempuan dicabut dan tidak berlaku lagi, dengan pertimbangan bahwa sunat perempuan hingga saat ini tidak merupakan tindakan kedokteran, karena pelaksanaannya tidak berdasarkan indikasi medis dan belum terbukti bermanfaat bagi kesehatan. Selain itu juga khitan perempuan dianggap sudah tidak sesuai lagi dengan dinamika perkembangan kebijakan global (Kementerian Kesehatan RI, 2014). Selain itu, 
wakil Menteri Kesehatan, Ali Qufron Mukti, menyatakan bahwa alasan pencabutan tersebut dikarenakan banyaknya pemikiran masyarakat yang menganggap khitan perempuan di Indonesia adalah sama dengan khitan perempuan yang dilakukan di Afrika, yaitu dengan memutilasi kelamin perempuan (female genital mutilation) (VOA Indonesia, 2014).

Pemikiran-pemikiran masyarakat yang dimaksud dalam ungkapan wakil Menteri Kesehatan tersebut tidak jauh berbeda dengan istilah yang diberikan WHO tentang khitan perempuan, yaitu Female Genital Cutting (FGC) atau Female Genital Mutilation (FGM) atau mutilasi alat kelamin perempuan. Menurut WHO, definisi FGM ialah meliputi seluruh prosedur yang menghilangkan secara total atau sebagian dari organ genitalia eksterna atau melukai pada organ kelamin wanita karena alasan non-medis (Mianoki, n.d.).

Berdasarkan penjelasan dari kedua objek tersebut, dapat disimpulkan bahwa landasan terbitnya Fatwa MUI No. 9A Tahun 2008 berbeda dengan landasan terbitnya PERMENKES No. 6 Tahun 2014. Landasan terbitnya Fatwa MUI No.9A Tahun 2008 ialah mereka melihat adanya berbagai dampak negatif yang ditemukan lebih sebagai akibat dari penyimpangan dari praktik khitan perempuan. Hal ini dikarenakan ketidak cukupan pengetahuan masyarakat khususnya tenaga medis seputar khitan perempuan. Berdasarkan hal tersebut, MUI dalam fatwanya memberi himbauan kepada Menteri Kesehatan untuk memberikan penyuluhan dan pelatihan kepada segenap tenaga medis dalam melakukan khitan atau sunat perempuan.

Adapun landasan terbitnya PERMENKES No.6 Tahun 2014 ialah karena praktik sunat perempuan dinilai melanggar hak reproduksi dan bertentangan dengan kebijakan pemerintah untuk menyehatkan perempuan. Khitan ini juga dianggap lebih cenderung menghilangkan libido perempuan. Hal ini juga di setujui oleh sekelompok aktivis perempuan yang menolak kebolehan khitan tersebut dengan alasan bahwa khitan bagi perempuan dapat memicu praktek sunat ilegal dan juga dapat menimbulkan traumatik terhadap anak perempuan.

\section{Khitan Perempuan dalam Fatwa MUI No. 9A Tahun 2008 dan PERMENKES No. 6 Tahun 2014 Tinjauan Maqashid Al-Syari'ah}

Dalam penelitian ini terdapat dua objek berbeda yang menjadi bahan penelitian, yaitu Fatwa MUI No. 9A Tahun 2008 dan PERMENKES No. 6 Tahun 2014. Namun keduanya mempunyai kesamaan yaitu dalam membahas khitan bagi perempuan. Sebagaimana telah dijelaskan dalam poin-poin di atas, masih terdapat banyak perbedaan pendapat dalam menghukumi khitan bagi perempuan ini, terutama dalam Fatwa MUI No. 9A Tahun 2008 dan PERMENKES No. 6 Tahun 2014 tersebut. Dalam fatwa MUI dijelaskan bahwa khitan bagi perempuan hukumnya adalah makrumah (memuliakan). MUI berpendapat demikian karena khitan bagi perempuan merupakan salah satu syariat Islam dan pelaksanaannya merupakan salah satu bentuk ibadah yang di anjurkan. 
Hal tersebut telah sesuai dengan aturan dalam hukum Islam yang bertujuan untuk hifdz al-diin (menjaga agama), yang mana jika kita mengamalkan salah satu syariat Islam maka sama halnya dengan kita menjaga sebuah agama dan sama halnya juga dengan kita mensyiarkan Islam. Juga dalam Islam tidak ada unsur paksaan dalam beribadah, seperti halnya khitan. Ketika ingin mengkhitankan perempuan, sebaiknya meminta persetujuan darinya terlebih dahulu, namun jika ia tidak berkehendak maka tidak ada keharusan untuk memaksanya.

Selain dapat menjaga agama, khitan juga dapat menjaga jiwa (hifdz al-nafs) seorang perempuan. Dianggap dapat menjaga jiwa, karena khitan yang dilakukan dengan cara yang benar akan menimbulkan dampak baik terutama kepada kesehatan perempuan tersebut. Namun berbeda halnya jika khitan dilakukan dengan sembarangan, akan berdampak buruk terutama kepada perempuan yang di khitan. Karena selain mengakibatkan pendarahan, juga dapat berakibat pada kematian. Guna mencegah terjadinya suatu hal yang tidak di inginkan, maka MUI telah menetapkan batasan-batasan atau tata cara mengkhitan seorang perempuan, yaitu dengan 3 hal: 1) sedikit saja, 2) tidak berlebihan, dan 3) tidak menimbulkan bahaya. Dengan mengikuti tata cara tersebut, maka tidak akan ada kematian pada perempuan ketika di khitan.

Kemudian dalam peraturannya, Menteri Kesehatan menolak dan mencabut PMK No. 1636/2010 tentang khitan bagi perempuan dengan salah satu alasan bahwa khitan tersebut tidak termasuk dalam tindakan medis, juga tidak terkandung manfaat di dalamnya, seperti yang terdapat dalam PERMENKES No. 6/2014 huruf (a) bahwa setiap tindakan yang dilakukan dalam bidang kedokteran harus berdasarkan indikasi medis dan terbukti bermanfaat secara ilmiah, (b) bahwa sunat perempuan hingga saat ini tidak merupakan tindakan kedokteran karena pelaksanaannya tidak berdasarkan indikasi medis dan belum terbukti bermanfaat bagi kesehatan" (Kementerian Kesehatan RI, 2014, sec. Menimbang (a) dan (b)). Juga dalam poin selanjutnya, Menteri Kesehatan juga menjelaskan bahwa khitan bagi perempuan dipandang tidak lagi sesuai dengan dengan dinamika perkembangan kebijakan global (Kementerian Kesehatan RI, 2014).

Tujuan dari adanya peraturan ini adalah untuk menjaga jiwa perempuan (hifdz al-nafs). Karena seperti yang telah di jelaskan pada pembahasan sebelumnya, menurut para kelompok aktivis perempuan, PMK No. 1636/2010 yang bersifat "permisif" terhadap khitan/sunat perempuan justru dapat memicu praktek sunat ilegal terhadap anak perempuan. Kemudian penggunaan jarum dan penjelasan langkah-langkah yang harus diambil oleh tenaga medis, dinilai dapat memicu terjadinya perlukaan dan trauma pada wanita (Dokter Anakku, 2015).

Selanjutnya, dalam hal untuk mengetahui kejelasan hukumnya, peneliti membandingkan kedua objek tersebut di atas dengan melihat manfaat khitan bagi perempuan menggunakan tinjauan maqashid al-syari'ah. Seperti yang telah dijelaskan pada pembahasan sebelumnya, 
bahwa perbedaan penetapan hukum bagi khitan perempuan antara PERMENKES dan fatwa MUI adalah karena mereka memiliki persepsi yang berbeda dan melihat kemaslahatan khitan perempuan dari sisi yang berbeda. Namun perbedaan tersebut tetaplah memiliki tujuan sendiri, yaitu untuk menjaga unsur-unsur pokok yang tercantum dalam pembahasan maqashid alsyari'ah, yaitu agama dan jiwa.

Karena sesuai dengan definisi dari maqashid al-syari'ah yaitu mewujudkan kemaslahatan bagi manusia dan menghindarkan mafsadat (kerusakan) bagi mereka. Dan untuk mewujudkan kemaslahatan itu ialah dengan menjaga kelima unsur pokok yang ada pada manusia atau dengan menjaga salah satu dari lima unsur yaitu agama, jiwa, akal, harta dan keturunan.

Selanjutnya, khitan bagi perempuan bukanlah sebuah kebutuhan primer, seperti yang telah dijelaskan dalam pembagian tingkatan maqashid al-syari'ah yaitu maqashid al-dharuriyat, yang mana kebutuhan pada tingkat ini harus dan bahkan wajib di penuhi. Jika tidak di penuhi, maka akan merusak kehidupan manusia secara keseluruhan baik di dunia maupun di akhirat. Khitan bagi perempuan ini adalah termasuk dalam tingkat maqashid al-tahsiniyat atau merupakan sebuah kebutuhan pelengkap saja, yang jika di penuhi akan membawa rasa nyaman dalam kehidupan manusia, namun jika tidak di penuhi tidak akan membawa kerusakan pada kehidupan manusia.

\section{KESIMPULAN}

Berdasarkan hasil paparan data yang telah di jelaskan sebelumnya, peneliti memberikan 2 kesimpulan terkait studi komparatif fatwa MUI No. 9A tahun 2008 dan PERMENKES No. 6 tahun 2014 tentang khitan bagi perempuan tinjauan maqashid al-syari'ah. Pertama, Fatwa MUI No. 9A tahun 2008 dan PERMENKES No.6 tahun 2014 mempunyai landasan atau dasar yang berbeda. Alasan dari munculnya fatwa ini ialah untuk menghidupkan sunnah adanya khitan pada perempuan sebagai tanda pemuliaan bagi para perempuan. Selain itu juga karena banyaknya masyarakat yang masih kebingungan akan hukum pasti dari khitan bagi perempuan, bahkan ada juga larangan dari tenaga kesehatan untuk melakukan khitan, karena dianggap membahayakan kesehatan. Kemudian dengan berlandaskan pada ayat-ayat al-quran dan haditshadits yang menerangkan tentang syariat khitan perempuan, maka diputuskanlah fatwa MUI yang menjelaskan bahwa hukum khitan bagi perempuan ialah makrumah (pemuliaan bagi perempuan), dengan alasan bahwa khitan perempuan merupakan salah satu dari syariat agama dan jika dilakukan dengan benar dan sesuai dengan syariat Islam, maka tidak akan membahayakan kesehatan. Kemudian dalam peraturannya, Menteri Kesehatan mengeluarkan peraturan terbaru No. 6 tahun 2014 yang berisi tentang Pencabutan terhadap PMK No. 1636 tahun 2010 tentang Khitan bagi Perempuan yang terdapat dalam Pasal (1). Pencabutan ini 
berdasarkan pada banyaknya fenomena yang terjadi di masyarakat Indonesia khususnya masyarakat pedesaan, dimana khitan bagi perempuan ini dilakukan dengan alat yang tidak steril (silet), dan pemotongannya (klitoris) dengan berlebihan sehingga mengakibatkan banyak pendarahan juga banyak mengakibatkan kematian pada perempuan yang di khitan. Alasan lain dari adanya peraturan baru ini ialah disebabkan oleh adanya fenomena praktek khitan perempuan yang tidak higienis yang cenderung menghilangkan libido perempuan.

Kedua, yaitu Jika ditinjau menggunakan maqashid al-syari'ah, khitan peremuan dalam fatwa MUI adalah menekankan pada syiar Islam yaitu menjaga agama (hifdz al-diin) dan menjaga jiwa (hifdz al-nafs). Dikatakan dapat menjaga agama ialah karena jika umat Islam mengamalkan salah satu syariat Islam, maka sama halnya dengan menjaga agama Islam dan mensyiarkan Islam. Sedangkan dianggap dapat menjaga jiwa seorang perempuan, karena khitan yang dilakukan dengan cara yang benar akan menimbulkan dampak baik terutama kepada kesehatan perempuan tersebut. Banyak manfaat yang akan di dapat untuk perempuan yang telah di khitan dengan batas-batas yang telah ditentukan, terutama ketika setelah berumah tangga, diantaranya ialah: dapat menstabilkan syahwat dari seorang perempuan ketika berhubungan badan dengan suaminya. Namun jika ketika di khitan tidak sesuai dengan ketentuan-ketentuan yang telah di jelaskan, maka perempuan tersebut akan terganggu psikisnya, juga dorongan seksualnya akan dingin sehingga membuat suami tidak dapat menikmatinya. Kemudian khitan perempuan dalam PERMENKES No. 6/2014 jika di tinjau menggunakan maqashid al-syari'ah adalah untuk menjaga jiwa (hifdz al-nafs). Dalam hal ini PERMENKES No. 6/2014 hanya melihat pada sisi medisnya saja. Selanjutnya, larangan khitan perempuan dalam PERMENKES adalah untuk menjaga agar tidak membahayakan kondisi psikis maupun fisik perempuan. Karena apabila khitan dilakukan dengan tidak benar, maka akan menimbulkan banyak pendarahan dan bahkan bisa berakibat pada kematian.

\section{DAFTAR PUSTAKA}

Abdullah, M. A., \& et al. (2006). Metode penelitian agama: Pendekatan multidisipliner. Yogyakarta: Karunia kalam Semesta.

Alfanjari, A. S. (2005). Nilai kesehatan dalam syari'at Islam. Jakarta: Bumi Aksara.

Alhafidz, A. W. (2007). Fikih kesehatan. Jakarta: Amzah.

Amiruddin, \& Asikin, Z. (2010). Pengantar metode penelitian hukum. Jakarta: PT. RajaGrafindo Persada.

Dokter Anakku. (2015). Pencabutan Permenkes sunat perempuan. Retrieved November 1, 2016, from http://dokteranakku.net/articles/2015/02/pencabutan-permenkes-sunatperempuan.html.

Kementerian Kesehatan RI. (2010). Peraturan Menteri Kesehatan Nomor 1636 Tahun 2010 
Tentang Sunat Perempuan, Tanggal 15 November 2010. Jakarta, Indonesia: Berita Negara Republik Indonesia Tahun 2010 Nomor 672.

Kementerian Kesehatan RI. (2014). Peraturan Menteri Kesehatan Nomor 6 Tahun 2014 Tentang Pencabutan PMK Nomor: 1636/MENKES/PER/XI/2010 Tentang Sunat Perempuan, Tanggal 7 Februari 2014. Jakarta, Indoensia: Berita Negara Republik Indonesia Tahun 2014 Nomor 185.

Konsideran Fatwa MUI-DIY No. 9A Tahun 2008.

Mianoki, A. (n.d.). Polemik khitan wanita. Retrieved November 1, 2016, from https://muslim.or.id/11314-polemik-khitan-wanita.html.

Sayuti, H. (1989). Pengantar metodologi riset. Jakarta: CV. Fajar Agung..

Siraj, F. M. (2013). Khitan bagi perempuan ditinjau dari kesehatan dan Islam. Retrieved November 2, 2016, from https://www.kompasiana.com/aufklarung/khitan-bagiperempuan-ditinjau-dari-kesehatan-dan-islam_552b74786ea834c7538b45b2

Subhan, Z. (2008). Menggagas fiqh pemberdayaan perempuan. Jakarta: El-Kahfi.

Utomo, S. B. (2003). Fiqh aktual. Jakarta: Gema Insani Press.

VOA Indonesia. (2014). Peraturan Menteri Kesehatan RI soal sunat perempuan telah dicabut. Retrieved November 2, 2016, from https://www.voaindonesia.com/a/peraturan-menterikesehatan-ri-soal-sunat-perempuan-telah-dicabut/1839905.html. 